\title{
The Effect of Company Size, Operating Profit/Loss, and Reputation of KAP Auditor on Audit Delay
}

\author{
M. Ridwan Tikollah, Samsinar \\ Program Studi Pendidikan Akuntansi Fakultas Ekonomi Universitas Negeri Makassar \\ Email: m.ridwan.tikollah@unm.ac.id
}

(Received: March 16-2019; revised: March 29-2019; published: May 31-2019)

\begin{abstract}
This associative-causal study aimed determine the effect of company size, operating profit/loss, and reputation of the Public Accountant Firm (Kantor Akuntan Publik/KAP) auditor on audit delay, simultaneously and partially; and which of both variables dominantly affect audit delay of banking companies listed on the Indonesia Stock Exchange (IDX). The research population was all banking companies listed on the IDX, while the samples were 30 banking companies taken by purposive sampling technique. Data collection was done by documentation techniques. Data analysis was carried out by: (1) data test (classic assumption test), and (2) hypothesis test, including: multiple linear regression analysis, F test, and t test. The results showed: (1) company size, operating profit/loss, and reputation of KAP auditor simultaneously affect audit delay, (2) company size had a negative effect on audit delay, thus the larger size of the company would need shorter time on audit delay; the profit/loss of the company had a positive effect audit delay, thus when the company was profit would need longer time on audit delay; reputation of KAP auditor had no effects on audit delay, thus Big Four KAP and non Big Four KAP carried our audit need the same period time; (3) company size had a dominant effect on audit delay, thus the auditors carried out audit dominantly affected by company size.
\end{abstract}

Keywords: company size; operating profit/loss; reputation of KAP auditor; audit delay

\section{INTRODUCTION}

Law Number 8 of 1995 concerning Capital Market stated that all companies registered in the capital market must submit financial statementss regularly to the Capital Market Supervisory Agency and Financial Institution (Indonesia: Badan Pengawas Pasar Modal dan Lembaga Keuangan/Bapepam-LK) and announce it to the public. If the company was late in submitting financial statementss, it would be subject to administrative sanctions (Jamaluddin, Sari, Akib, Kasmita, \& Tadampali, 2019; Tadampali, Hadi, \& Salam, 2016). In 1996, the Chairperson of the Bapepam-LK issued Decree Number 80/PM/1996 which required every public company to submit annual financial statementss and independent auditor reports to Bapepam-LK no later than 120 days after the date of the company's annual financial statements. However, since September 30, 2003, Bapepam has increasingly tightened with the Decree of the Chairperson of Bapepam Number Kep-36/PM/2003 wherein Appendix 2 stated that the annual v must be accompanied by an Accountant's report with a common opinion and submitted to Bapepam no later than the end of the third month after the date of the annual financial statements.

Since December 31, 2012, the duties and functions of Bapepam-LK switch to the Financial Services Authority (OJK). In Article 7 of the OJK Regulation Number 29/POJK04/2016 concerning the Annual Report of Issuers or Public Companies, it stated that the issuer or public 
88 | Jurnal Ilmiah Ilmu Administrasi Publik: Jurnal Pemikiran dan Penelitian Administrasi Publik

Volume 9 Number 1, January - June 2019. Page 87-94

company must submit an annual report to OJK no later than the end of the fourth month after the financial year ends. Thus, the auditor had a time span in conducting an audit to issue an audit report, which was called audit delay.

Audit delay was the period of completion of the audit measured from the closing date of the financial year to the date of the issuance of the audit report (Suryanto, 2016). The factors that effect on audit delay had been tested by several researchers. These factors were generally viewed from the aspect of the company and from the aspect of the auditor. Based on the results of several previous studies, it could be seen that there was a consequence of the effect of company size on audit delay in Amani \& Waluyo (2016); Apriyana \& Rahmawati (2017); Cahyanti, Sudjana, \& Azizah (2016); Owusu-Ansah (2000); Rubianto (2017); Subekti \& Widiyanti (2004) which showed that company size had a negative effect on audit delay. However, the effect of operating profit/loss on audit delay could be seen as inconsistencies. Kartika's research (2009) showed that operating profit/loss affect audit delay, while Kartika's research (2011) showed that operating profit/loss didn't affect audit delay. Inconsistencies could be seen also in the effect of auditor reputation/KAP on audit delay. The results of the Subekti \& Widiyanti (2004) study showed that the auditor's reputation/size affect audit delay, while the results of Suryanto (2016); Utami (2018), and Angruningrum \& Wirakusuma (2013) research showed that the reputation of auditor/KAP had no effect on audit delay.

Indonesia Stock Exchange (IDX) was one of the capital market institutions in Indonesia (Khairan, Tikollah, \& Anwar, 2018). At present there were 618 companies listed on the IDX which were divided into three classifications of industry, namely: major, manufacturing, and services. The classifications were divided into several sectors, and each sector was divided into several sub-sectors respectively. One of sub-sector of the service industry was the bank subsector. The data of company size data (total assets), operating profit/loss, and reputation of KAP auditor of banking companies listed on the IDX in 2017 showed an inconsistency in the effect of company size, profit/loss, and reputation of KAP auditor on audit delay.

\section{METHOD}

This research was an associative-quantitative study that explained the effect of company size, operating profit/loss, and reputation of KAP auditor on audit delay of banking companies listed on the IDX. The population of this study was all banking companies listed on the IDX in 2017 which number 30 companies. The sample selection technique used was purposive sampling with considerations and criteria: (1) companies that had been listed on the IDX during 2017, (2) the company was included in the category of banking companies, (3) the companies published audited financial statements and independent auditor's reports, (4) The company used Rupiah in its financial statements. Based on the sample selection criteria above, all banking companies listed on the IDX in 2017 meet the criteria for being selected so that the population was also be sample in this study (using census sample method). Data collection techniques used in this study were: documentation, obtained through the IDX website (www.idx.co.id).

The research variables were operationally defined as follows:

1. Audit delay was the period of completion of the audit by auditor, measured by the closing date of the financial year to the date stated in the independent auditor's report of the 
banking company listed on the IDX. This variable was measured by the number of days from book closing to the date of the independent auditor's report.

2. Company size was the classification scale of large/small companies that were judged by the nominal size of the banking companies listed on the IDX. This variable was measured by total assets. Because the total asset value was quite large, then for the purposes of data analysis a transformation was made into natural logarithms (Ln).

3. Operating profit/loss was profit earned from the main operations of a banking company listed on the IDX. This variable was measured by the profit or loss experienced by the company. Thus, for the purposes of data analysis, a dummy was used, where the company that obtains profit was given a value of 1 while the company that experiences loss was given a value of 0 .

4. Reputation of KAP auditor was the criteria of KAP auditor of banking companies listed on the IDX. This variable was measured by the status of the audtior's company including KAP or its affiliates in the Big Four or non-Big Four. Thus, for the purposes of data analysis a dummy was used, where the banking company audited by the Big Four KAP was given a value of 1 while the banking company audited by non-Big Four KAP was given a value of 0 .

The data analysis technique used in this study consisted of: (1) test of data (classical assumption test), which included: normality test was carried out by Kolmogorof-Smirnov test at a significance level $(\alpha)$ of 0.05 ; heteroscedasticity test was carried out by the Glejser test; multicollinearity test was done by the Variance Inflation Factor (VIF) test, (2) hypothesis testing, which includes: multiple regression analysis, $\mathrm{F}$ test, and $\mathrm{t}$ test.

\section{RESULT AND DISCUSSION}

\section{Research Object}

The biggest companies of the 30 banking companies listed on the IDX in 2017 was BBRI with total assets of Rp1,126.25 billion and the smallest was BINA with total assets of Rp3,12 billion. Companies that earn profits were 25 companies and those losses there were five companies. There were 22 companies audited by KAPs affiliated with the Big Four and eight companies audited by KAPs non-Big Four. The longest audit delay was BBKP with an audit time of 90 days and the shortest completion of the audit was BKSW with an audit time of 15 days.

\section{Results of Data Analysis}

\section{Results of Test of Data (Classical Assumption Test)}

The results of classical assumption test showed the following:

a. Normality test using the Kolmogorof-Smirnov test at a significance level $(\alpha)$ of 0.05 , obtained a probability value of 0.127 greater than the significance level $(\alpha)(0.127>0.05)$. Thus, the data used in the regression model was normally distributed, so that it could be used for multiple regression models.

b. Heteroscedasticity test using Glejser test obtained probability value (sig.) of company size 0.201 , operating profit/loss 0.306 , and reputation of KAP auditor 0.057 greater than the 
90 Jurnal Ilmiah Ilmu Administrasi Publik: Jurnal Pemikiran dan Penelitian Administrasi Publik Volume 9 Number 1, January - June 2019. Page 87-94

significance level $(\alpha)(0.201,0.306,0.057>0.05)$. Thus, there were no symptoms of heteroscedasticity in the regression model.

c. Multicollinearity test using Variance Inflation Factor Test (VIF) obtained VIF value of company size 1.030, operating profit/loss 1.042, and reputation of KAP auditor 1.047. This showed that the VIF value of company size, operating profit/loss, and the reputation of KAP auditor smaller than $10(1.030,1.042,1.047<10)$. Thus, between the variable company size, operating profit/loss, and reputation of KAP auditor multicollinearity occured.

\section{Results of Hypothesis Testing}

Results of Multiple Linear Regression Analysis

The results of multiple linear regression analysis were presented in Table 3. Based on the results of data analysis in Table 3, the regression equation was obtained as follows:

$\mathrm{Y}=209,737-9,053 \mathrm{X} 1+21,987 \mathrm{X} 2-15,815 \mathrm{X} 3$

Results of F Test (Simultaneous Test)

The result of $\mathrm{F}$ test were presented in Table 1 . Based on the results of data analysis in Table 1 , the probability value of $\mathrm{F} 0,000$ was smaller than the significance level $(\alpha)(0,000<0,05)$. This showed that company size, operating profit/loss, and reputation of KAP auditor simultaneously affect audit delay of banking companies listed on the IDX.

Furthermore, the results of coefficient of determination analysis obtained the results as in Table 2. Based on the data in Table 2 obtained the coefficient of determination of $\mathrm{R}$ Square of 0.521 or 52.1 percent. This showed that the audit delay variable could be explained by 52.1 percent by the variable size of the company, operating profit/loss, and reputation of KAP auditor.

Result of $t$ Test (Partial Test )

The results of $t$ test were presented in table 3 . Based on the results of data analysis in table 3 , the results could be interpreted as follows:

1. Probability value of company size of 0.001 was smaller than the significance level $(\alpha)$ $(0.001<0.005)$ with a negative direction. This showed that the company size partially had a negative effect on audit delay.

2. Probability value of operating profit/loss of 0.028 was smaller than the significance level $(\alpha)$ $(0.028<0.005)$ with a positive direction. This showed that the operating profit/loss partially had a positive effect on audit delay.

3. Probability value of the reputation of KAP auditor of 0.064 was greater than the significance level $(\alpha)(0.064>0.005)$ with a negative direction. This showed that the reputation of KAP auditor partially had no effect on audit delay.

$\mathrm{T}$ value of the company size of 3.857 was greater than the $t$ value of operating profit/loss of $2.322(3.857>2.322)$. This showed that the company size dominantly affect audit delay. 
Table 1

Result of F Test

\begin{tabular}{|c|c|c|c|c|c|}
\hline & $\begin{array}{l}\text { Sum of } \\
\text { Squares }\end{array}$ & $\mathrm{df}$ & $\begin{array}{c}\text { Mean } \\
\text { Square }\end{array}$ & $\mathrm{F}$ & Sig. \\
\hline Regression & 8412.681 & 3 & 2804.227 & 9.413 & $.000^{\mathrm{b}}$ \\
\hline Residual & 7745.619 & 26 & 297.908 & & \\
\hline Total & 16158,300 & 29 & & & \\
\hline
\end{tabular}

a. Dependent Variable: audit delay

b. Predictors: (Constant), company size, operating profit/loss, reputation of KAP auditor

Table 2

Result of Coefficient of Determination

\begin{tabular}{rccc}
\hline $\mathrm{R}$ & $\mathrm{R}$ Squares & Adjusted R Squares & Std. Error of the Estimate \\
\hline $.722^{\mathrm{a}}$ & .521 & .465 & 17.26002 \\
\hline a. & Predictors: (Constant), company size, operating profit/loss, reputation of KAP auditor \\
b. & Dependent Variable: audit delay (Y)
\end{tabular}

Table 3 Result of t Test

\begin{tabular}{|c|c|c|c|c|c|}
\hline \multirow[t]{2}{*}{ Model } & \multicolumn{2}{|c|}{$\begin{array}{l}\text { Unstandardized } \\
\text { Coefficients }\end{array}$} & \multirow{2}{*}{$\begin{array}{c}\begin{array}{c}\text { Standardized } \\
\text { Coefficients }\end{array} \\
\text { Beta } \\
\end{array}$} & \multirow[t]{2}{*}{$\mathrm{t}$} & \multirow[t]{2}{*}{ Sig. } \\
\hline & B & Std. Error & & & \\
\hline (Constant) & 209.737 & 36.821 & & 5.696 & .000 \\
\hline Company Size & -9.053 & 2.347 & -.633 & -3.857 & .001 \\
\hline Operation Profit/Lost & 21.987 & 9.470 & .353 & 2.322 & .028 \\
\hline Reputation of KAP Auditor & -15.815 & 8.168 & -.288 & -1.936 & .064 \\
\hline
\end{tabular}

a. Dependent Variable: Audit delay

The Effect of Company Size, Operating Profit/Loss, and Reputation of KAP Auditor Simultaneously on Audit Delay

The results of hypothesis testing indicate that company size, operating profit/loss, and reputation of KAP auditor simultaneously affect audit delay which could predict audit delay by 52.1 percent. This means that audit delay was affected by other variables outside the variables studied at 47.9 percent.

The Effect of Company Size, Operating Profit/Loss, and Reputation of KAP Auditor Partially on Audit Delay

\section{The Effect of Company Size on Audit Delay}

The results of hypothesis testing indicated that company size had a negative effect on audit delay, which means that for the larger size of company, the audit delay would be shorter. Conversely the smaller size of company, the audit delay would be longer. This was because the 
92 Jurnal Ilmiah Ilmu Administrasi Publik: Jurnal Pemikiran dan Penelitian Administrasi Publik Volume 9 Number 1, January - June 2019. Page 87-94

larger companies had a good internal control system so that it could reduce the level of financial statement errors and then facilitate auditor in auditing financial statements (Owusu-Ansah, 2000; Puspitasari \& Latrini, 2014). In addition, large the companies would complete the audit process faster than small companies because the large-scale companies management tends to reduce audit delay because these companies were closely monitored by investors, capital supervisors, and the government ((Amani \& Waluyo, 2016; Angruningrum \& Wirakusuma, 2013; Apriyana \& Rahmawati, 2017; Cahyanti et al., 2016; Owusu-Ansah, 2000; Rubianto, 2017; Subekti \& Widiyanti, 2004; Suryanto, 2016; Utami, 2018).

\section{The Effect of Operating Profit/Loss on Audit Delay}

The results of hypothesis testing indicated that operating profit/loss had a positive effect on audit delay, which mean that if the company earned profits, the audit delay would be longer. Conversely, if the company experienced a loss, the audit delay would be shorter. This was because the announcement of companies experiencing profits had consequences for the distribution of profits in the form of dividend to shareholders. To be able to fulfill this, the companies need time to prepare what they need.

These results were not in line with the results of Suryanto (2016) which showed that operating profit/loss had a negative effects on audit delay, and Kartika's (2011) research results showed that operating profit/loss had no effect on audit delay.

\section{The Effect of Reputation of KAP Auditor on Audit Delay}

The results of hypothesis testing indicated that the reputation of KAP auditor had no effect on audit delay, which means that the Big Four KAP and non-Big Four KAP required relatively the same audit delay. This was due to technology and specialist staff possessed by the Big Four KAP and non Big Four KAP relatively the same. The results of this study were in line with the results of Kartika's research (2009), Kartika (2011), and Angruningrum \& Wirakusuma (2013) which indicated auditor size/reputation/KAP had no effect on audit delay. However, these results were not in line with the results of the study of Subekti \& Widiyanti (2004), Lee \& Jahng (2008) and Türel (2010) which showed that the auditor's reputation /size/KAP had effect on audit delay.

\section{Dominant Effect of Company Size, Operating Profit/Loss, or Reputation of KAP Auditor on Audit Delay}

The results of hypothesis testing indicated that company size had a dominant effect on audit delay, which mean that auditor in carried out audit dominantly affected by company size. This was due to the company size being a factor that would directly affected the audit activities.

\section{CONCLUSION}

Company size had a negative effect on audit delay, which means that for the larger size of company, the audit delay would be shorter. Operating profit/loss had a positive effect on audit 
delay, which means that if the company earned a profit, the audit delay will be longer. Reputation of KAP auditor had no effect on audit delay, which means that the Big Four and non Big Four KAPs in carried out audit require relatively the same time. Company size had a dominant effect on audit delay, which mean that auditor in carried out audit dominantly affected by company size. This was due to the company size being a factor that would directly affected the audit activities.

\section{REFERENCES}

Amani, F. A., \& Waluyo, I. (2016). Pengaruh Ukuran Perusahaan, Profitabilitas, Opini Audit, Dan Umur Perusahaan Terhadap Audit Delay (Studi Empiris pada Perusahaan Property dan Real Estate yang Terdaftar di Bursa Efek Indonesia pada Tahun 2012-2014). Nominal, Barometer Riset Akuntansi Dan Manajemen, 5(1).

Angruningrum, S., \& Wirakusuma, M. G. (2013). Pengaruh profitabilitas, leverage, kompleksitas operasi, reputasi KAP dan komite audit pada audit delay. E-Jurnal Akuntansi, 251-270.

Apriyana, N., \& Rahmawati, D. (2017). Pengaruh Profitabilitas, Solvabilitas, Ukuran Perusahaan, dan Ukuran Kap Terhadap Audit Delay Pada Perusahaan Properti dan Real Estate yang Terdaftar di Bursa Efek Indonesia Periode 2013-2015. Nominal, Barometer Riset Akuntansi Dan Manajemen, 6(2).

Cahyanti, D. N., Sudjana, N., \& Azizah, D. F. (2016). Pengaruh Ukuran Perusahaan, Profitabilitas, dan Solvabilitas Terhadap Audit Delay (Studi Pada Perusahaan LQ 45 SubSektor Bank serta Property dan Real Estate yang Terdaftar di Bursa Efek Indonesia (BEI) Tahun 2010-2014). Jurnal Administrasi Bisnis, 38(1), 68-73.

Jamaluddin, J., Sari, W. I., Akib, H., Kasmita, M., \& Tadampali, A. C. T. (2019). The Influence of Spirit at Work on Employee Productivity at PT Millenium Penata Futures Makassar. Pinisi Business Administration Review, 1(1), 11-20.

Khairan, A. T., Tikollah, M. R., \& Anwar, A. (2018). Analisis Perbandingan Mekanisme Pemberian Kredit Produktif dan Pembiayaan Mudharabah pada PT BNI (persero) Tbk Sentra Kredit Kecil dan PT BNI Syariah Kantor Cabang Utama Makassar. Universitas Negeri Makassar.

Lee, H., \& Jahng, G. (2008). Determinants of audit report lag: Evidence from Korea-an examination of auditor-related factors. Journal of Applied Business Research, 24(2), 27.

Owusu-Ansah, S. (2000). Timeliness of corporate financial reporting in emerging capital markets: Empirical evidence from the Zimbabwe Stock Exchange. Accounting and Business Research, 30(3), 241-254.

Rubianto, A. V. (2017). The Analysis on Factors Affecting Audit Delay on Manufacturing Companies Listed in Indonesia Stock Exchange. Jurnal Riset Dan Aplikasi: Akuntansi Dan Manajemen, 2(3), 205-214.

Subekti, I., \& Widiyanti, N. W. (2004). Faktor-faktor yang berpengaruh terhadap audit delay di 
94| Jurnal Ilmiah Ilmu Administrasi Publik: Jurnal Pemikiran dan Penelitian Administrasi Publik Volume 9 Number 1, January - June 2019. Page 87-94

Indonesia. Simposium Nasional Akuntansi, 7(1), 991-1002.

Suryanto, T. (2016). Audit delay and its implication for fraudulent financial reporting: a study of companies listed in the Indonesian stock exchange. European Research Studies, 19(1), 18.

Tadampali, A. C. T., Hadi, A., \& Salam, R. (2016). Pengaruh Iklim Organisasi terhadap Turnover Intention Melalui Kepuasan Kerja sebagai Variabel Intervening pada PT Bank SulSelBar. Jurnal Ilmiah Ilmu Administrasi Publik, 6(2), 35-46.

Türel, A. G. (2010). Timeliness of financial reporting in emerging capital markets: Evidence from Turkey. European Financial and Accounting Journal, 5(3-4), 113-133.

Utami, F. (2018). Analysis Determined Audit Delay (An Empirical Study On Mining Companies Listed In Indonesian Stock Exchange During 2012-2016). Proceeding of International Seminar \& Conference on Learning Organization. 